\title{
Strategies, patterns and environmental cues for reproduction in two temperate haliclonid sponges
}

\author{
D. A. Abdo ${ }^{1, *}$, J. Fromont ${ }^{2}$, J. I. McDonald ${ }^{1}$ \\ ${ }^{1}$ School of Plant Biology (M090), Faculty of Natural and Agricultural Sciences, University of Western Australia, \\ 35 Stirling Highway, Crawley, Western Australia 6009, Australia \\ ${ }^{2}$ Department of Aquatic Zoology, Western Australian Museum, Locked Bag 49, Welshpool DC, Western Australia 6986, Australia
}

\begin{abstract}
The reproductive biology of 2 haliclonid sponges was examined over a 2 yr period. Histological samples of Haliclona sp. 1 (green Haliclona) and Haliclona sp. 2 (brown Haliclona) from tagged and haphazardly sampled individuals of both species were examined using light microscopy. Interest in these 2 sympatric species is high, due to the potent and unique bioactive compound (salicylihalamide A) they produce, hence the need to understand the reproductive biology of both species to ensure their proper conservation and management. Green Haliclona is viviparous, with both gonochoric and hermaphroditic individuals in the sponges sampled. Brown Haliclona is also viviparous and is clearly a gonochoric species. Only decreasing wave height showed a significant correlation to gametogenesis, but the onset and progression of reproduction in both species coincided with increases in water temperature and photoperiod. Oogenesis for both species extended from November to April. Spermatogenesis extended over 3 mo for green Haliclona (January to March) and 4 mo for brown Haliclona (January to April). Embryogenesis within brood chambers started in January and extended over 4 mo in green Haliclona and 5 mo in brown Haliclona. The parenchymellae larvae of green Haliclona were observed in tissue samples for 2 mo compared to 4 mo for brown Haliclona. The reproductive output of each species was similar; however, female reproductive output at $2.9 \%$ (green Haliclona) and $2.4 \%$ (brown Haliclona) of the mesohyl was much lower than that of other viviparous species. Male reproductive output 2.3 and $2.4 \%$ for green and brown Haliclona, respectively) compares favourably to that of oviparous species. The high reproductive output of males and the timing of reproduction in both species of sponge appears to help in reducing the risk of unsuccessful fertilisation and lower the probability of larvae being released into unfavourable conditions.
\end{abstract}

KEY WORDS: Haliclona $\cdot$ Sexual $\cdot$ Fecundity $\cdot$ Gametogenesis Resale or republication not permitted without written consent of the publisher

\section{INTRODUCTION}

Sponges often dominate reef fauna, particularly in temperate regions (Fromont 1999). They inhabit all areas of the oceans from tropical (De Weerdt 2000) to polar (Barnes 1995) waters, from intertidal zones (Barnes 1999) to the deep sea (Witte 1996). Their presence in these habitats may, in part, be related to their successful application of a variety of reproductive strategies (Simpson 1980), from asexual reproduction such as fragmentation (i.e. mechanical separation of parts) (Wulff 1991), budding (Corriero et al. 1998), or formation of gemmules (Fell 1995) to sexual reproduction including viviparity (Ilan 1995), oviparity (Mariani et al. 2000), gonochorism (Witte et al. 1994) and various forms of hermaphroditism (Simpson 1984, Riesgo et al. 2007). Initiation and regulation of sponge reproduction has been linked to environmental factors, including water temperature (Simpson 1980, Fromont 1994b, Witte et al. 1994, Fell 1995, Corriero et al. 1998, Ereskovsky 2000, Mercurio et al. 2007), food availability (Simpson 1980, Witte 1996), photoperiod and lunar 
phase (Simpson 1980, Fromont 1994a, Usher et al. 2004). Despite broad biological knowledge, understanding of the role of reproduction in the structuring and maintenance of sponge populations is limited (but see Whalan et al. 2005, Zilberberg et al. 2006, Riesgo et al. 2007, Whalan et al. 2007).

While the reproductive biology of many sponge taxa has been well documented in the northern hemisphere (e.g. Elvin 1976, Barthel 1986, Wapstra \& van Soest 1987, Ilan \& Loya 1990, Ilan 1995, Tsurumi \& Reiswig 1997, Corriero et al. 1998, Ereskovsky 2000, Lepore et al. 2000, Mercurio et al. 2007, Riesgo et al. 2007), fewer studies have been undertaken in Australia (Fromont 1994a,b, Fromont 1999, Usher et al. 2004, Whalan et al. 2005, 2007), particularly for temperate species (Fromont 1999, Usher et al. 2004, Whalan et al. 2005). Further, many studies do not examine how reproductive biology influences sponge population dynamics. The paucity of knowledge may be due to the difficulties of studying reproduction where the target organism does not have designated gonads (Bergquist 1978). In addition, understanding the reproductive biology of some species is complicated by the co-occurrence of both sexual and asexual reproduction within the same populations (Battershill \& Bergquist 1990, Maldonado \& Uriz 1999).

As sponges are now being recognised as one of the richest sources of marine natural products (Munro et al. 1999, McClintock \& Baker 2001, Paul et al. 2006), commercial demand for secondary metabolites may place increasing pressure on harvesting wild populations. Maintenance of a population is intimately linked to the reproductive strategy employed (Doherty 1994). Therefore, knowledge of the reproductive biology of the targeted organism is essential for the effective management and conservation of the organism's population.

The overall aim of the present study was to provide a detailed description of the reproductive biology of 2 sympatric sponge species (Haliclona sp. 1 and Haliclona sp. 2) that have received considerable attention from natural product chemists due to the production of a potent cytotoxic natural product, salicylihalamide A (Erickson et al. 1997). Sponges of Haliclona sp. 1 (hereafter green Haliclona; Western Australian Museum Voucher Z37485) have a massive morphology, with large chimney-like oscules (Abdo 2007). Haliclona sp. 2 (hereafter brown Haliclona; Western Australian Museum Voucher Z37486) individuals have a main body supported by a short basal stalk, with a submassive mound shape and numerous small oscules (Abdo 2007). This study was aimed to determine: (1) mode of reproduction, (2) sequence and synchrony of reproductive development, (3) relationships between size and levels of reproductive output, and (4) environmental cues of reproduction.

\section{MATERIALS AND METHODS}

Sampling procedure. The reproductive biology of Haliclona sp. 1 (green Haliclona) and Haliclona sp. 2 (brown Haliclona) was investigated at Hamelin Bay $\left(34.20^{\circ} \mathrm{S}, 115.04^{\circ} \mathrm{E}\right)$ on the southwest coast of Australia from November 2004 to May 2006. No sampling was undertaken between June 2005 and October 2005 due to the closure of the boat access point during winter. Samples of tagged individuals ( $\mathrm{N}=15$ for each species) and haphazardly selected individuals $(\mathrm{N}=53$ for green Haliclona, $\mathrm{N}=47$ for brown Haliclona) were taken monthly in $2004 / 2005$, but only the tagged individuals were sampled in 2005/2006. Comparisons between reproductive periods using periodic regression (detailed below) indicate that the pattern of reproduction reported here was not influenced by the reduction in sampled individuals or by repeated sampling of tagged individuals.

The size of tagged sponges was determined using an underwater stereo camera to capture a series of stereo images of each sponge (Abdo et al. 2006). Each set of images was then processed in the laboratory to obtain a volume estimate for each sponge (Abdo et al. 2006).

Reproductive elements in some species of sponge can either occur throughout the mesohyl (Bergquist 1978) or be isolated in certain areas (Fromont 1999), and a pilot study was undertaken to determine the distribution of reproductive elements within the mesohyl for both species of Haliclona studied (Whalan et al. 2007). Tissue was taken from the sponge surface (top $5 \mathrm{~cm}$ ), from the middle of the mesohyl and from basal regions of reproductive individuals $(\mathrm{N}=10$ from each species). A 1-way ANOVA (Zar 1999) confirmed that reproductive elements were not confined to specific regions, with no significant differences in the numbers of elements between regions of the sponge for both green Haliclona $(F=0.55, \mathrm{df}=2, \mathrm{p}=0.581)$ and brown Haliclona $(F=0.09, \mathrm{df}=2, \mathrm{p}=0.917)$. Data were checked for normality and homogeneity of variance.

Histology. In the main study, tissue samples were collected by divers on SCUBA by cutting a small piece of tissue (approximately $4 \mathrm{~cm}^{3}$ ) haphazardly from each individual. The excised tissue was placed into histology cassettes and fixed in gonad fixative (FAACC$100 \mathrm{ml}=10 \mathrm{ml}$ of $10 \%$ formaldehyde solution, $5 \mathrm{ml}$ of $5 \%$ glacial acetic acid, $1.3 \mathrm{~g}$ of calcium chloride dihydrate and $85 \mathrm{ml}$ of tap water) after collection (Fromont 1999, Whalan et al. 2007). After 48 h, samples were transferred into $70 \%$ ethanol until histological preparation.

Using a histological tissue processor, samples were run through an alcohol and xylene sequence, and impregnated under vacuum with paraffin wax. Samples were blocked in paraffin wax and sectioned at 
$8 \mu \mathrm{m}$ with a microtome. Tissue sections were stained with haematoxylin \& eosin, mounted and examined by light microscopy to identify reproductive elements (Fromont 1999, Whalan et al. 2007).

Determination of reproductive output (RO). Using a digital camera (Olympus C5050) mounted onto a light microscope (Olympus CH2), digital images were captured of the reproductive elements within each tissue section. Digital imaging software (ReproMeasure by SeaGIS: www.seagis.com.au) was used to calculate the diameters and area of reproductive elements. The area of the tissue section was also determined to allow the calculation of the reproductive output (RO) for each sponge sampled, and the number of reproductive elements per $\mathrm{mm}^{2}$.

RO was calculated by determining the total area of reproductive elements within the total area of sectioned tissue (i.e. percentage of reproductive elements per $\mathrm{mm}^{2}$ ). Total reproductive output for each sponge $\left(\mathrm{RO}_{\mathrm{t}}\right)$ was calculated by converting $\mathrm{RO}$ to a volume (multiplying the RO by the thickness of the section, i.e. $8 \mu \mathrm{m})$, then multiplying this by the volume of the sponge (Whalan et al. 2007).

Reproductive elements were classified as oocytes, embryos, larvae, or spermatocysts. The relatively low numbers of oocytes, embryos and larvae allowed the counting and measurement (i.e. area and diameter) of all the reproductive elements within each tissue section (Whalan et al. 2007). As spermatocysts had a much greater abundance, the total number of spermatocysts was determined by counting all spermatocysts within 5 separate haphazardly selected fields of view (FOV). The counts from each FOV (equivalent to $1 \mathrm{~mm}^{2}$ ) were then averaged for the tissue section (Whalan et al. 2007). Measurements of spermatocyst diameter and area were made of 10 spermatocysts from each of the 5 FOV and averaged for each tissue section. Oocytes were only measured when sectioned through the nucleus, whereas embryos, larvae and spermatocysts were measured if sectioned medially. Following Whalan et al. (2007), the accuracy of RO as a measure of reproductive output was examined by analysis of the correlation (using Pearson's correlation coefficient $r_{\text {; }}$ Zar 1999) between RO and the total number of reproductive elements. A significant correlation was observed between the RO and total number of reproductive elements for both green Haliclona (males [including those with oocytes]: $r=0.918, p<0.001$; females: $r=0.917$, $\mathrm{p}<0.001$ ) and brown Haliclona (males: $\mathrm{r}=0.931$, $\mathrm{p}<$ 0.001; females: $\mathrm{r}=0.894, \mathrm{p}=<0.001)$. This indicates that RO is a valid measure of reproductive output for both species (Whalan et al. 2007).

Physical data. Water temperatures were recorded at Hamelin Bay using 2 Onset StowAway Tidbit temperature loggers, which were sampled at hourly intervals.
These data were averaged to give monthly temperature for the sampling period. Photoperiod data were obtained by calculating the total hours of sunlight from sunrise and sunset times (for Hamelin Bay) obtained from Geosciences Australia (www.ga.gov.au/geodesy/ astro/sunrise.jsp), and were averaged over each month. Wave height data were obtained from the Western Australian Department of Planning and Infrastructure's Coastal Data Centre (www.dpi.wa.gov.au/imarine/ 13461.asp). Hourly measurements of total wave height were averaged to give mean total wave height for each month over the study period.

Statistical analysis. Periodic regression was used to determine the cyclical patterns of RO for each reproductive period (Year 1: 2004/2005; Year 2: 2005/2006) separately for each sponge species (Batschelet 1981, deBruyn \& Meeuwig 2001). In periodic regression, the independent variable is an angular representation of time, where the yearly data is divided into $360^{\circ}$ to give each month an angular equivalent, $\theta$ (deBruyn \& Meeuwig 2001). The transformed data are then analyzed by simple linear regression (deBruyn \& Meeuwig 2001). This technique was used because it is more powerful, robust and less sensitive to missing data, which is common in the cyclical data recorded in reproduction studies (Batschelet 1981, deBruyn \& Meeuwig 2001). The slopes of the periodic regression analysis were compared using a $t$-test (Zar 1999) to determine if there was a difference in the RO between years for each sponge species. Data were checked for normality prior to analysis.

To determine any correlations between reproductive output (both for $\mathrm{RO}$ and $\mathrm{RO}_{\mathrm{t}}$ ) and sponge size (Whalan et al. 2007), Pearson's correlation coefficient was calculated for both male and female sponges (Zar 1999). $t$-tests were used to test for differences in the sizes of sponges with oocytes and embryos, compared to those which did not produce female reproductive elements for each species separately (Zar 1999). Data were checked for normality prior to analysis. Pearson's r was also used to test for correlations between the percentage of reproductive sponges and RO (pooled for males and females) for each sponge species, with water temperature, photoperiod and total wave height. Bonferroni corrections were applied for the correlation analyses.

\section{RESULTS}

\section{Reproductive cycle}

Green Haliclona was viviparous, brooding both eggs and larvae, with examples of gonochorism and hermaphroditism. Female sponges were reproductive from November through April. Male sponges were reproductive for 3 mo (January to March) (Fig. 1a). During 
Female $\square$ Male $\square$ Both $\square$ Not Reproductive

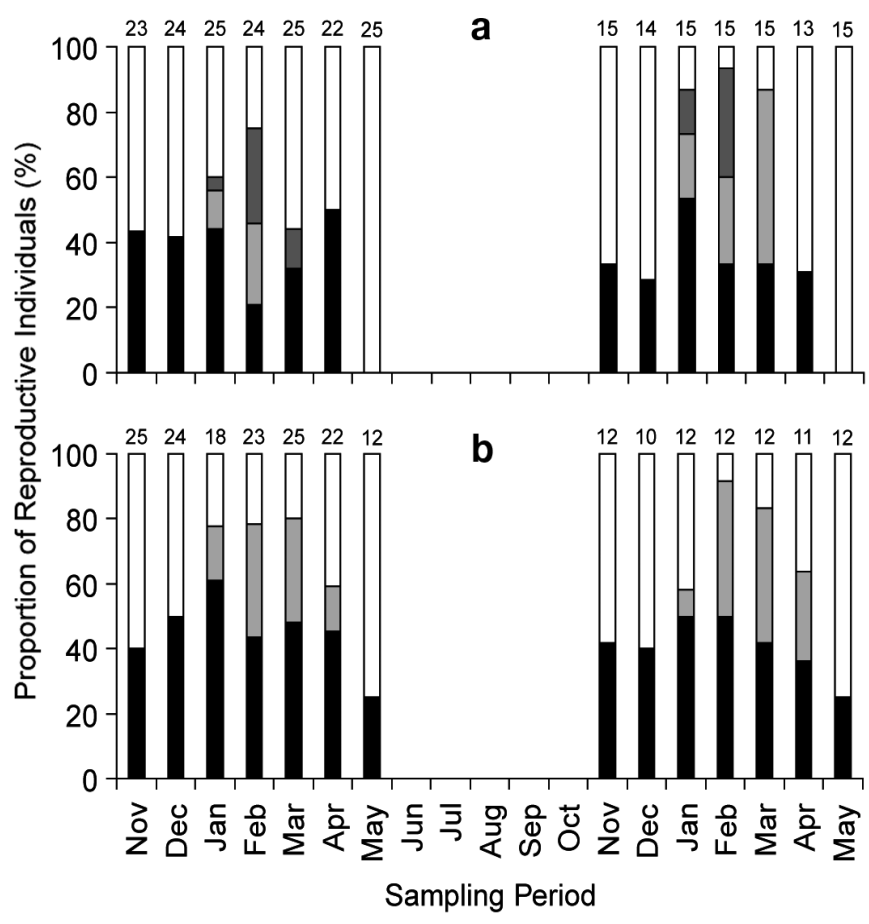

Fig. 1. Haliclona spp. Proportion of female, male and nonreproductive sponges for: (a) green and (b) brown Haliclona. No sampling took place between June and October. Numbers above each bar represent the total numbers of sponges sampled for each month

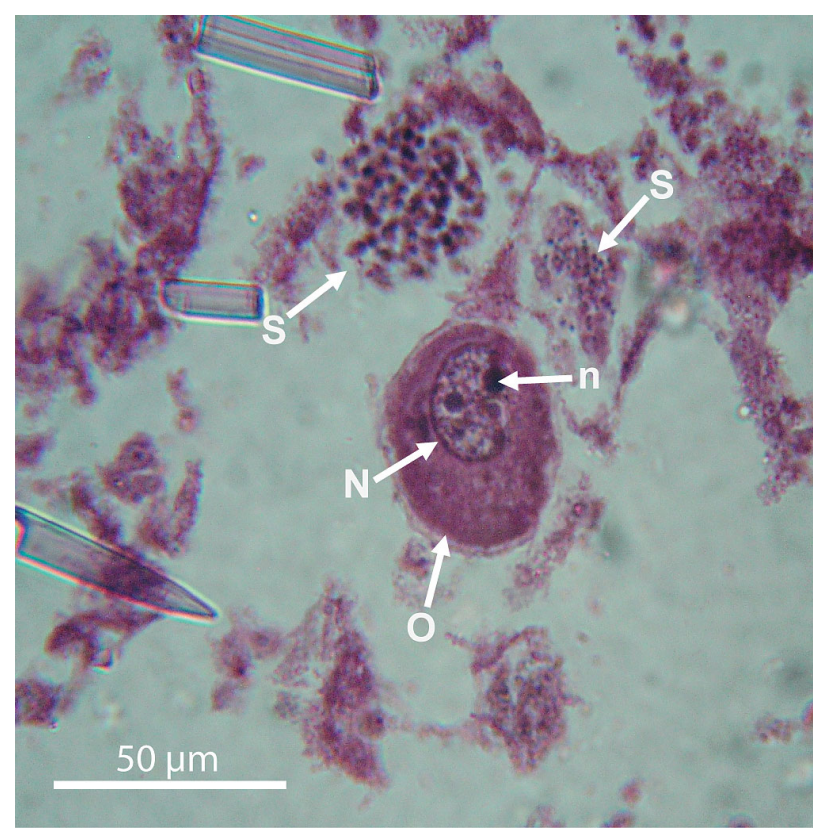

Fig. 2. Haliclona sp. 1. Oocytes present in male sponges of green Haliclona between January and March. S: spermatocyst; O: oocyte; N: nucleus; n: nucleolus of oocyte this period several male sponges were found to have oocytes and spermatocysts present within their tissue (Fig. 2); however these sponges were never observed to produce embryos or larvae. No reproductive individuals were present after April (Fig. 1a).

Brown Haliclona was also viviparous, developing male and female reproductive elements in separate individuals and clearly showing this species to be gonochoric. Female and male reproductive elements were never observed in the same individual during the study period. Female sponges were reproductive over the entire sampling period (November to May) and male sponges were reproductively active from January to April (Fig. 1b). In brown Haliclona, reproduction was still evident when sampling ceased in May. No samples were taken from June to October, and interpretations are based on the 7 mo (from both years) during which samples were taken.

\section{Reproductive development}

Spermatogenesis

Spermatogenesis in both species occurs asynchronously (within an individual) throughout the mesohyl, but is synchronous within a spermatocyst. Also, spermatogenesis was asynchronous among individuals during the 3 mo spermatocysts were present in the mesohyl. Spermatic cysts were observed in green Haliclona from January until March and were spherical in shape, with mean cyst diameter measuring $26.3 \pm 1.7 \mu \mathrm{m}( \pm \mathrm{SE})$ (Fig. 3a). In brown Haliclona, spermatic cysts were observed from January through to April and were also spherical in shape, with a mean diameter of $26.3 \pm 2.8 \mu \mathrm{m}$ ( \pm SE) (Fig. 3b).

\section{Oogenesis, embryogenesis and larval development}

Green Haliclona had consistent timing and periods of oogenesis, embryogenesis and larval development over both reproductive periods (Fig. 4a). Oogenesis occurred from at least November, extending asynchronously both within and among individuals until April. Oocyte size remained similar over this period, with a mean oocyte diameter of $51.1 \pm 2.7 \mu \mathrm{m}$ (mean $\pm \mathrm{SE}$ ) (ranging from 45.1 to $59.1 \mu \mathrm{m}$ ). Oocytes were spherical to elliptical in shape, with a large nucleus and nucleolus (Fig. 5a). Oocytes present in sponges producing spermatocysts were significantly $(t$-test: $t=-5.05, \mathrm{df}=$ $72, \mathrm{p}<0.01)$ smaller in mean $( \pm \mathrm{SE})$ size $(36.9 \pm 1.4 \mu \mathrm{m})$ than those observed in female sponges $(54.9 \pm 2.4 \mu \mathrm{m})$.

Embryogenesis occurred within brood chambers throughout the sponge mesohyl, indicating migration of 

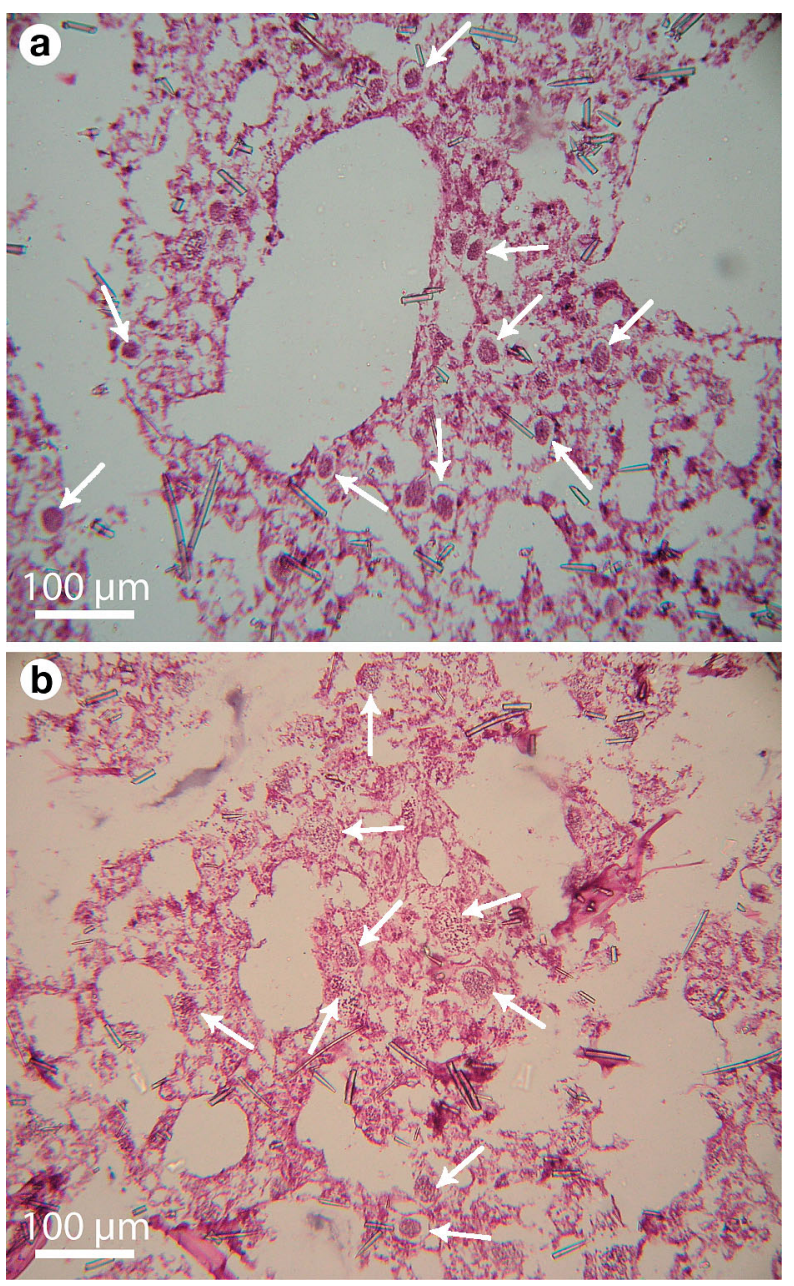

Fig. 3. Haliclona spp. Spermatocysts present in male sponges of: (a) green and (b) brown Haliclona. Arrows indicate spermatocysts

oocytes to these reproductively active regions. Embryos were first observed in January (Figs. 4a \& 5b). Embryo development was asynchronous within and between brood chambers among individual sponges (Fig. 5c). The mean $( \pm \mathrm{SE})$ diameter of embryos increased from January $(130.9 \pm 14.1 \mu \mathrm{m})$ to a maximum mean size $(454.9 \pm 36.0 \mu \mathrm{m})$ in March. Embryos decreased in mean $( \pm \mathrm{SE})$ size $(299.1 \pm 60.4 \mu \mathrm{m})$ in April, and no embryos were present in May (Table 1, Fig. 4a).

The first parenchymellae larvae were observed in March and were present within brood chambers for 2 mo (Fig. 4a). Green Haliclona larvae had a mean $( \pm \mathrm{SE})$ length of $1041 \pm 22 \mu \mathrm{m}$ and could be distinguished from embryos due to differentiation of the larval epithelium of columnar cells (Fig. 5d).

The timing of oogenesis, embryogenesis and larval development in brown Haliclona was also similar for both years over the sampling period (Fig. 4b). Oogenesis extended from November until April

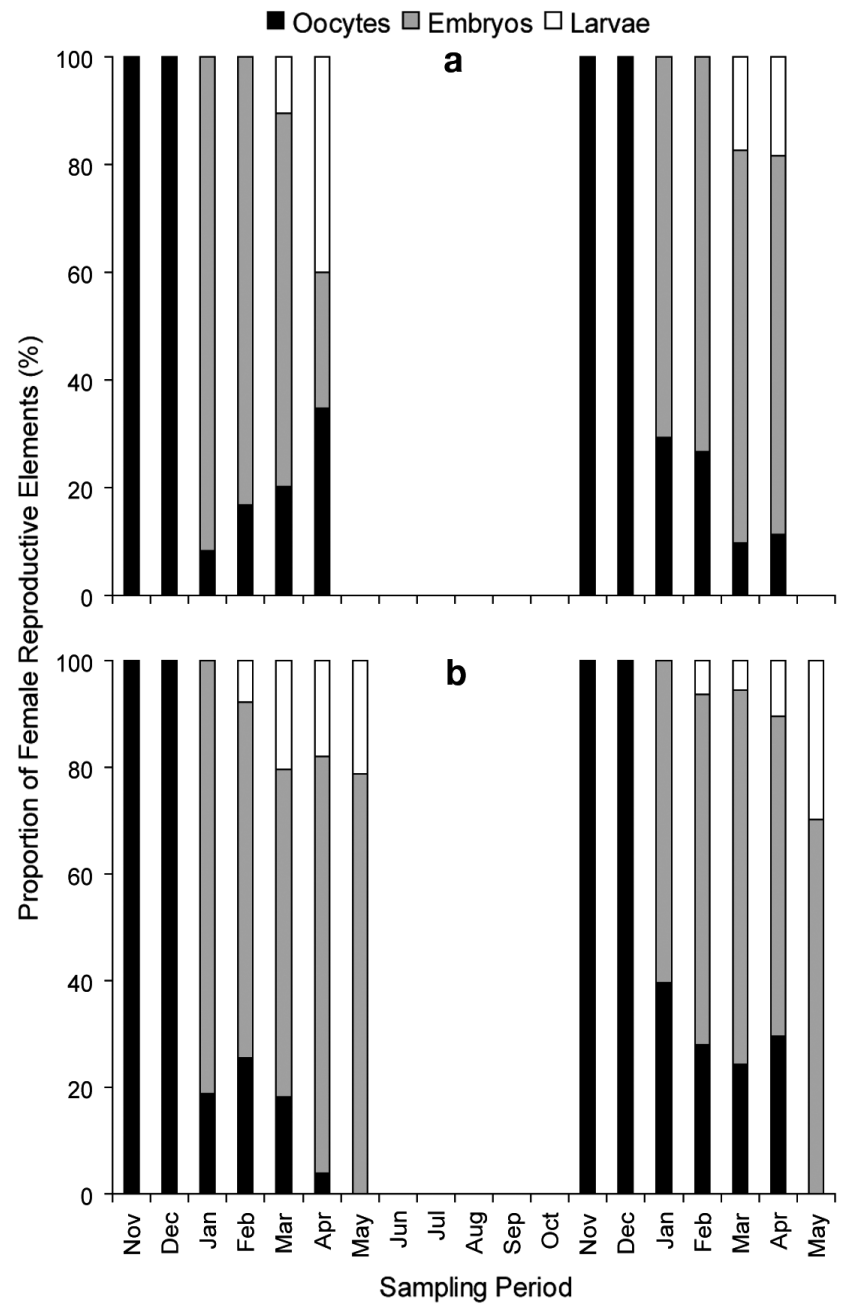

Fig. 4. Haliclona spp. Timing of oogenesis, embryogenesis and larval development in: (a) green and (b) brown Haliclona.

No sampling took place between June and October

throughout the mesohyl. Oocyte size was also consistent over this period with a mean $( \pm \mathrm{SE})$ oocyte diameter of $67.3 \pm 2.2 \mu \mathrm{m}$ (ranging from 61.1 to $75.5 \mu \mathrm{m}$ ), with a large nucleus and nucleolus (Fig. 6a). Embryogenesis in brown Haliclona extended from January through to May (Fig. 4b), with several stages of development present within a brood chamber. Brood chambers were found throughout the sponge mesohyl, and similarly oocytes appear to have migrated into brood chambers as observed for green Haliclona (Fig. 6b,c). Embryogenesis was asynchronous within and between brood chambers, as well as among individuals. Embryo mean $( \pm$ SE) size increased from $262.8 \pm 40.3 \mu \mathrm{m}$ in January to a peak during March $(474.5 \pm 67.5 \mu \mathrm{m})$ (Fig. 6b). Embryos decreased in size to a mean ( \pm SE) of $297.5 \pm 51.2 \mu \mathrm{m}$ in May. Brown Haliclona parenchymellae larvae were first observed in February, and were present within brood chambers until May, with a mean $( \pm$ SE) length of $1097 \pm 31 \mu$ m (Figs. 4b \& 6d). 

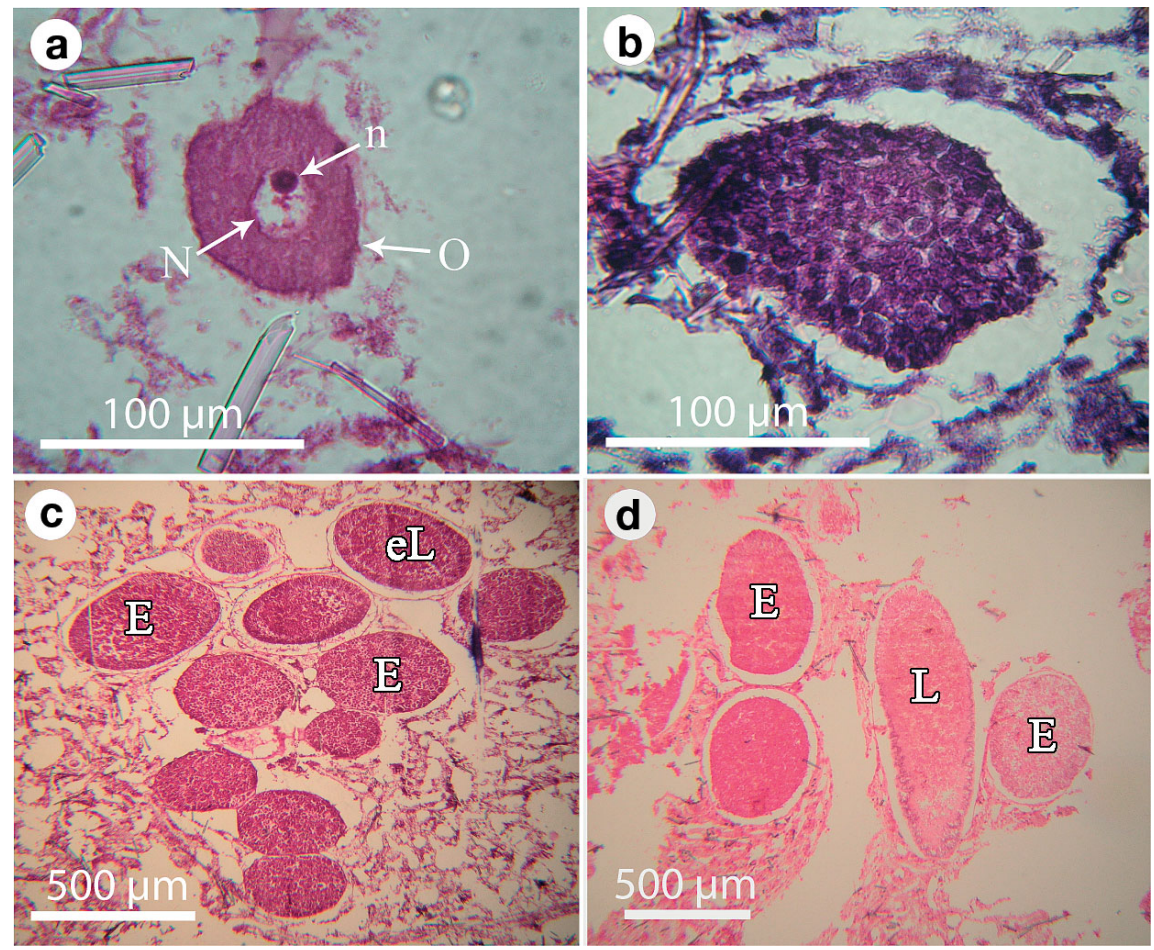

Fig. 5. Haliclona sp. 1. (a) Oogenesis, (b) early embryos, (c) brood chamber with different stages of embryogenesis and (d) larvae. N: nucleus; $\mathrm{n}$ : nucleolus; O: oocyte; L: larvae;

E: embryo; eL: early larval stage

Table 1. Haliclona spp. Density of propagules and percentage of reproductive tissue (i.e. reproductive capacity) for green and brown Haliclona. NS: no sampling

\begin{tabular}{|c|c|c|c|c|c|c|c|}
\hline & & $\begin{array}{l}\text { Spermatocysts } \\
\left(\text { no. } \mathrm{mm}^{-2}\right)\end{array}$ & $\begin{array}{l}\text { Oocytes } \\
\left(\text { no. } \mathrm{mm}^{-2}\right)\end{array}$ & $\begin{array}{l}\text { Embryos } \\
\left(\text { no. } \mathrm{mm}^{-2}\right)\end{array}$ & $\begin{array}{c}\text { Larvae } \\
\text { (ind. } \mathrm{mm}^{-2} \text { ) }\end{array}$ & $\% \sigma^{7}$ Tissue & \% o Tissue \\
\hline \multicolumn{8}{|c|}{ Green Haliclona } \\
\hline \multirow[t]{2}{*}{2004} & Nov & & $0.042( \pm 0.012)$ & & & & $0.006( \pm 0.002)$ \\
\hline & Dec & & $0.062( \pm 0.029)$ & & & & $0.006( \pm 0.002)$ \\
\hline \multirow[t]{7}{*}{2005} & Jan & $43.86( \pm 5.94)$ & $0.018( \pm 0.003)$ & $0.195( \pm 0.045)$ & & $2.34( \pm 0.37)$ & $1.18( \pm 0.277)$ \\
\hline & Feb & $22.06( \pm 2.53)$ & $0.026( \pm 0.005)$ & $0.132( \pm 0.026)$ & & $1.19( \pm 0.14)$ & $1.69( \pm 0.344)$ \\
\hline & Mar & $27.27( \pm 16.36)$ & $0.031( \pm 0.006)$ & $0.108( \pm 0.029)$ & $0.016( \pm 0.005)$ & $0.72( \pm 0.41)$ & $1.47 \quad( \pm 0.385)$ \\
\hline & Apr & & $0.028( \pm 0.004)$ & $0.020( \pm 0.002)$ & $0.032( \pm 0.007)$ & & $0.48 \quad( \pm 0.156)$ \\
\hline & Jun-Oct & NS & NS & NS & NS & NS & NS \\
\hline & Nov & & $0.051( \pm 0.008)$ & & & & $0.01 \quad( \pm 0.003)$ \\
\hline & Dec & & $0.084( \pm 0.022)$ & & & & $0.02 \quad( \pm 0.010)$ \\
\hline \multirow[t]{5}{*}{2006} & Jan & $19.04( \pm 5.60)$ & $0.033( \pm 0.009)$ & $0.080( \pm 0.031)$ & & $0.87( \pm 0.32)$ & $0.24 \quad( \pm 0.115)$ \\
\hline & Feb & $45.14( \pm 2.40)$ & $0.048( \pm 0.018)$ & $0.133( \pm 0.031)$ & & $2.06( \pm 0.12)$ & $1.23( \pm 0.439)$ \\
\hline & Mar & $18.18( \pm 3.07)$ & $0.025( \pm 0.005)$ & $0.185( \pm 0.021)$ & $0.044( \pm 0.015)$ & $0.48( \pm 0.12)$ & $2.92( \pm 0.524)$ \\
\hline & $\begin{array}{l}\text { Apr } \\
\text { May }\end{array}$ & & $0.014( \pm 0.007)$ & $0.087( \pm 0.032)$ & $0.022( \pm 0.003)$ & & $1.43( \pm 0.440)$ \\
\hline & Mean (overall) & $29.26( \pm 4.99)$ & $0.039( \pm 0.006)$ & $0.112( \pm 0.02)$ & $0.029( \pm 0.006)$ & $1.28( \pm 0.05)$ & $0.89 \quad( \pm 0.06)$ \\
\hline \multicolumn{8}{|c|}{ Brown Haliclona } \\
\hline \multirow[t]{2}{*}{2004} & Nov & & $0.064( \pm 0.012)$ & & & & $0.009( \pm 0.002)$ \\
\hline & Dec & & $0.043( \pm 0.007)$ & & & & $0.007( \pm 0.001)$ \\
\hline \multirow[t]{8}{*}{2005} & Jan & $18.13( \pm 5.47)$ & $0.028( \pm 0.005)$ & $0.123( \pm 0.051)$ & & $1.04( \pm 0.49)$ & $1.28( \pm 0.602)$ \\
\hline & Feb & $22.16( \pm 3.36)$ & $0.055( \pm 0.009)$ & $0.143( \pm 0.030)$ & $0.017( \pm 0.003)$ & $1.55( \pm 0.26)$ & $2.36 \quad( \pm 0.804)$ \\
\hline & Mar & $12.82( \pm 3.03)$ & $0.033( \pm 0.015)$ & $0.112( \pm 0.024)$ & $0.037( \pm 0.017)$ & $0.73( \pm 0.22)$ & $2.16 \quad( \pm 0.646)$ \\
\hline & Apr & $19.30( \pm 2.54)$ & $0.005( \pm 0.002)$ & $0.094( \pm 0.029)$ & $0.022( \pm 0.005)$ & $0.69( \pm 0.14)$ & $1.65( \pm 0.475)$ \\
\hline & May & & & $0.082( \pm 0.047)$ & $0.022( \pm 0.007)$ & & $1.38( \pm 0.897)$ \\
\hline & Jun-Oct & NS & NS & NS & NS & NS & NS \\
\hline & Nov & & $0.049( \pm 0.015)$ & & & & $0.02 \quad( \pm 0.005)$ \\
\hline & Dec & & $0.084( \pm 0.034)$ & & & & $0.03 \quad( \pm 0.015)$ \\
\hline \multirow{6}{*}{2006} & Jan & $14.80( \pm 3.89)$ & $0.064( \pm 0.021)$ & $0.097( \pm 0.025)$ & & $0.18( \pm 0.12)$ & $1.24 \quad( \pm 0.348)$ \\
\hline & Feb & $44.21( \pm 5.51)$ & $0.049( \pm 0.014)$ & $0.115( \pm 0.041)$ & $0.011( \pm 0.005)$ & $2.39( \pm 0.42)$ & $2.20 \quad( \pm 0.748)$ \\
\hline & Mar & $14.83( \pm 1.90)$ & $0.027( \pm 0.011)$ & $0.077( \pm 0.026)$ & $0.006( \pm 0.000)$ & $0.90( \pm 0.18)$ & $1.52( \pm 0.531)$ \\
\hline & Apr & $11.39( \pm 0.85)$ & $0.015( \pm 0.000)$ & $0.031( \pm 0.011)$ & $0.005( \pm 0.000)$ & $0.39( \pm 0.13)$ & $0.63( \pm 0.342)$ \\
\hline & May & & & $0.014( \pm 0.008)$ & $0.006( \pm 0.000)$ & & $0.11 \quad( \pm 0.082)$ \\
\hline & Mean (overall) & $19.704( \pm 3.72)$ & $0.043( \pm 0.006)$ & $0.089( \pm 0.013)$ & $0.016( \pm 0.004)$ & $0.99( \pm 0.05)$ & $1.04( \pm 0.09)$ \\
\hline
\end{tabular}


Fig. 6. Haliclona sp. 2. (a) Oogenesis, (b) early embryogenesis, (c) multiple stages of cleavage in brood chambers and (d) larvae. N: nucleus; n: nucleolus; O: oocyte; L: larvae; E: embryo
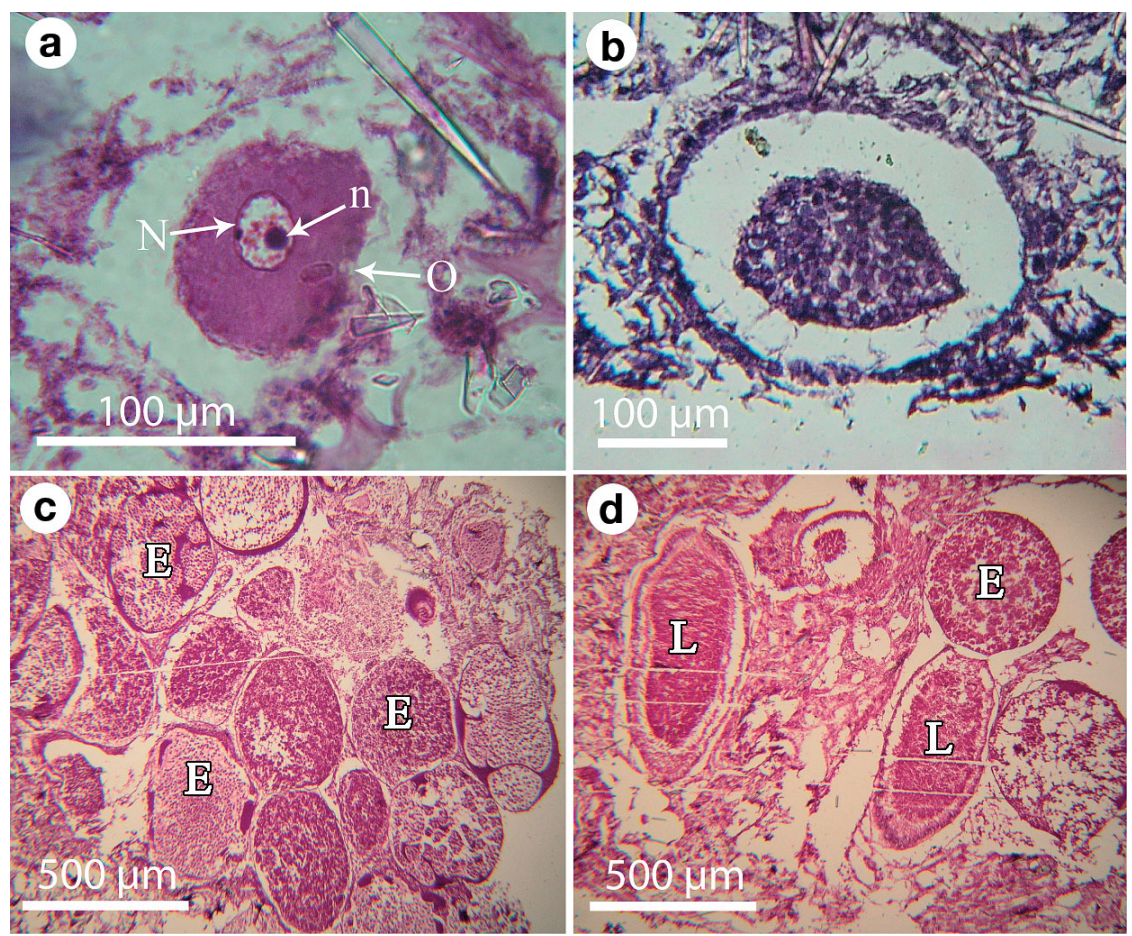

\section{Reproductive output}

RO was highest in males of green Haliclona, with a mean $( \pm \mathrm{SE})$ of $1.28 \pm 0.05 \%$ of the mesohyl devoted to gametes, whereas females had $0.89 \pm 0.06 \%$ of their mesohyl devoted to reproductive elements (Table 1). Reproductive output was highest for green Haliclona from January to March, when both male and female RO was at its peak (except for the second year, when high female RO extended to April) (Table 1). The density of reproductive elements (number per square millimetre) follows a similar trend, with greater mean $( \pm \mathrm{SE})$ numbers of male gametes $(29.3 \pm 5.0)$ compared to female elements $(0.13 \pm 0.02)$ per $\mathrm{mm}^{2}$. Reproductive output did not differ significantly between years ( $t$-test: $t=1.463, \mathrm{df}=10, \mathrm{p}<0.05)$ when the coefficients of the periodic regressions of $\mathrm{RO}$ for each reproductive period were compared. $\mathrm{RO}_{\text {Year } 1}=-0.396+2.80( \pm 0.84)$ $\operatorname{cosine}(\theta)+1.53( \pm 0.61) \operatorname{sine}(\theta) ; \mathrm{RO}_{\text {Year } 2}=0.248+2.27$ $( \pm 0.80) \operatorname{cosine}(\theta)+1.98( \pm 0.59) \operatorname{sine}(\theta)$.

The reverse situation occurred in brown Haliclona, where females had the highest RO at $1.04 \pm 0.09 \%$ $( \pm \mathrm{SE})$ compared to males with $0.98 \pm 0.05 \%$ of the mesohyl occupied by gametes. Reproductive output peaked in February for brown Haliclona, which coincided with peaks in both male $(1.55 \%$ [Year 1] and $2.39 \%$ [Year 2]) and female RO (2.36\% [Year 1] and $2.20 \%$ [Year 2]) (Table 1). The mean $( \pm \mathrm{SE})$ density of reproductive elements was higher in males $(19.7 \pm 3.7)$ compared to females $(0.138 \pm 0.023)$. There was no significant difference ( $t$-test: $t=0.76, \mathrm{df}=10, \mathrm{p}<0.05)$ in
$\mathrm{RO}$ of brown Haliclona between years $\left[\mathrm{RO}_{\text {Year } 1}=0.410\right.$ $+1.90( \pm 0.59) \operatorname{cosine}(\theta)+2.13( \pm 0.43) \operatorname{sine}(\theta) ; \mathrm{RO}_{\text {Year } 2}=$ $-0.373+2.66( \pm 1.03) \operatorname{cosine}(\theta)+1.95( \pm 0.76) \operatorname{sine}(\theta)]$.

\section{Size and reproductive output}

The size of individuals of green Haliclona ranged from 301 to $6976 \mathrm{~cm}^{3}$. The mean $( \pm \mathrm{SE})$ size of male sponges was $3247 \pm 954 \mathrm{~cm}^{3}$ (range 301 to $6976 \mathrm{~cm}^{3}$ ), compared to the mean $( \pm \mathrm{SE})$ size of female sponges at $2473 \pm 707 \mathrm{~cm}^{3}$ (range 587 to $4724 \mathrm{~cm}^{3}$ ). No significant correlation was found between male sponge size (including individuals producing oocytes) and RO ( $\mathrm{r}=$ $0.085, \mathrm{p}=0.828$ ). There was also no significant correlation between the size and RO of female green Haliclona ( $\mathrm{r}=0.659, \mathrm{p}=0.155)$. However, for both the male and female sponges there was a significant positive correlation between sponge size and $\mathrm{RO}_{\mathrm{t}}$ (male sponges: $r=0.928, p<0.01$; female sponges: $r=0.968$, $\mathrm{p}<0.01)$. There was no significant difference in size between sponges that produced embryos and those that did not ( $t$-test: $t=-0.76, \mathrm{df}=13, \mathrm{p}=0.460)$.

Brown Haliclona individuals ranged in size from 37 to $868 \mathrm{~cm}^{3}$. Male sponges had a mean $( \pm \mathrm{SE})$ size of $324 \pm 73 \mathrm{~cm}^{3}$ (range 124 to $750 \mathrm{~cm}^{3}$ ), whereas females had a mean $\left( \pm \mathrm{SE}\right.$ ) size of $316 \pm 141 \mathrm{~cm}^{3}$ (range 37 to $868 \mathrm{~cm}^{3}$ ). No significant correlation was observed between the size of male brown Haliclona and their RO ( $\mathrm{r}=0.157, \mathrm{p}=0.686)$, or between the size of females and their respective $\mathrm{RO}(\mathrm{r}=-0.309, \mathrm{p}=551)$. A signifi- 
cant positive correlation was found between sponge size and $\mathrm{RO}_{\mathrm{t}}$ for both the male and female brown Haliclona (males: $\mathrm{r}=0.872, \mathrm{p}<0.01$; females: $\mathrm{r}=0.975, \mathrm{p}<$ 0.01 ). There was also no significant difference between the size of female (i.e. produce oocytes) and male (i.e. no oocytes) sponges ( $t$-test: $t=-0.06, \mathrm{df}=13, \mathrm{p}=0.955$ ).

\section{Environmental cues}

Although RO in both Haliclona species coincided with increasing water temperature (Fig. 7a), there was no statistically significant correlation between water temperature and the percentage of sponges that were reproductively active (green Haliclona: $\mathrm{r}=-0.15$, $\mathrm{p}_{\alpha=0.017}=0.611$; brown Haliclona: $\mathrm{r}=0.02, \mathrm{p}_{\alpha=0.017}=$ 0.939 ) or the RO (green Haliclona: $\mathrm{r}=0.244, \mathrm{p}_{\alpha=0.017}=$

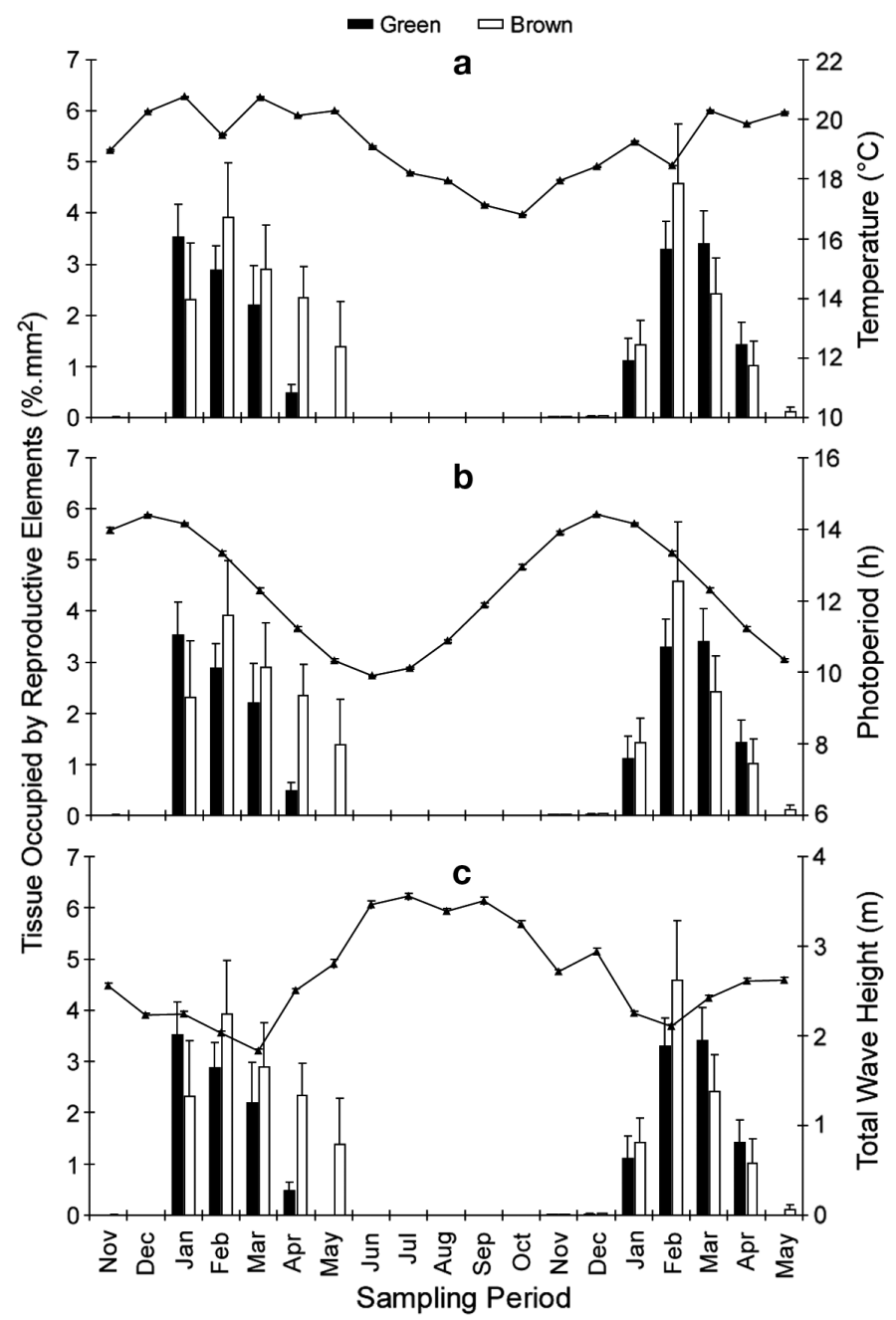

Fig. 7. Haliclona spp. Total reproductive capacity (i.e. \% tissue occupied by reproductive elements) for green and brown Haliclona, with (a) water temperature, (b) photoperiod and (c) total wave height. Note temperature and photoperiod axes do not begin at zero; no sampling between June and October

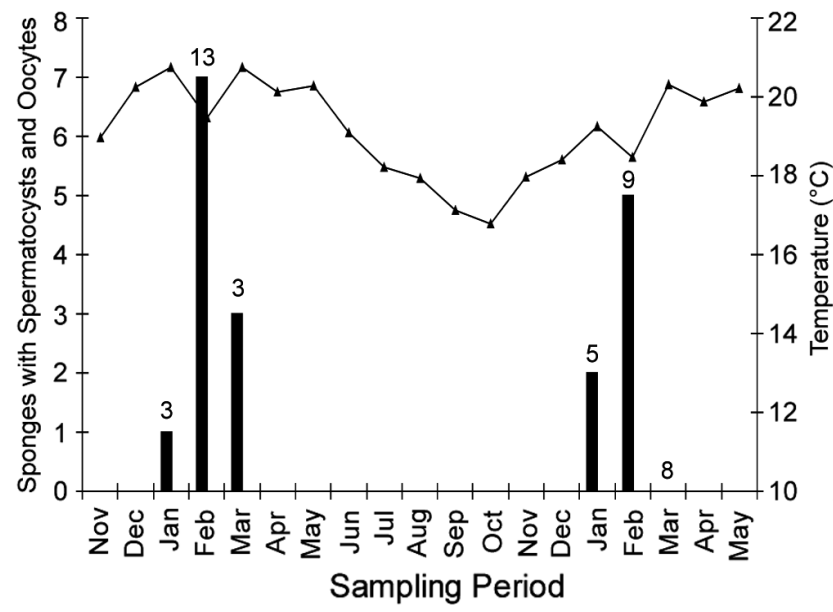

Fig. 8. Haliclona sp. 1. Number of male green sponges with oocytes and corresponding water temperature. Numbers above bars indicate total number of sponges with spermatocysts. Note temperature axis does not begin at zero, and sampling did not occur between June and October

0.400; brown Haliclona: $\left.\mathrm{r}=0.159, \mathrm{p}_{\alpha=0.017}=0.586\right)$. A significant drop in temperature was recorded in February (compared to January and March) (1-way ANOVA: $F=2539.19, \mathrm{df}=2, \mathrm{p}<0.01)$. It should be noted that the decrease in water temperature started at the end January and temperatures only began increasing after the beginning of March, which is not reflected in the monthly averages. The production of oocytes in males of green Haliclona also occurred during this time of decreasing water temperature (Fig. 8).

Reproductive onset for each species coincided with the maximum photoperiod (Fig. 7b). No significant correlation was found for either species between photoperiod and the percentage of reproductive individuals (green Haliclona: $\mathrm{r}=0.49, \mathrm{p}_{\alpha=0.017}=0.074$; brown Haliclona: $\mathrm{r}=0.33, \mathrm{p}_{\alpha=0.017}=0.243$ ) or the RO (green Haliclona: $\mathrm{r}=0.125, \mathrm{p}_{\alpha=0.017}=0.677$; brown Haliclona: $\mathrm{r}=-0.077, \mathrm{p}_{\alpha=0.017}=0.794$ ).

Increasing reproductive output coincided with a reduction in total wave height, and both variables were significantly correlated for green $\left(\mathrm{r}=-0.653, \mathrm{p}_{\alpha=0.017}=\right.$ $0.011)$ and brown Haliclona $\left(\mathrm{r}=-0.690, \mathrm{p}_{\alpha=0.017}<0.01\right)$. A significant correlation between total wave height and the percentage of reproductive individuals was also observed for green $\left(\mathrm{r}=-0.621, \mathrm{p}_{\alpha=0.017}=0.018\right)$ and brown Haliclona $\left(\mathrm{r}=-0.720, \mathrm{p}_{\alpha=0.017}=0.004\right)$ (Fig. $7 \mathrm{c}$ ).

\section{DISCUSSION}

\section{Reproductive development and sexuality}

Both haliclonid species examined in the present study were viviparous and brooded eggs and paren- 
chymellae larvae. These results are similar to studies of other species of Haplosclerida (Fromont 1994a,b, 1999) (Table 2). Viviparity is probably highly advantageous due to the protection of developing larvae, enhancing the chances of offspring survival and recruitment into suitable habitats (Ayling 1980, McEdward \& Miner 2003). However, greater investment of energy reserves into fewer larvae generally decreases the output of larvae, and thus the numbers of potential recruits (McEdward 1997). Understanding this is particularly important for the correct management and conservation of potentially exploitable species, such as the haliclonid sponges examined here.

Brown Haliclona was clearly gonochoric, while green Haliclona appears to be hermaphroditic, as oocytes were observed within the tissue of some male sponges. Although gonochorism cannot be excluded in green Haliclona, as some individuals only showed the presence of either male or female reproductive elements during the period of study. This is consistent with other haplosclerids in which both gonochoristic and hermaphroditic species have been recorded (Simpson 1984, Fromont 1994a,b). The production of oocytes by males has been reported previously in several haplosclerid species (e.g. Haliclona loosanoffi and H. permollis) and in other orders of sponge (e.g. Hymeniacidon sanguinea and Stelleta grubii) (Elvin 1976, Fell 1976, Simpson 1984, Wapstra \& van Soest 1987). The production of oocytes by males may be due to a proportion of the green Haliclona population being hermaphroditic, while other individuals within the population have a gonochoric habit. This has been reported previously (Lewandrowski \& Fell 1981, Simpson 1984, Wapstra \& van Soest 1987), as has the alternation between a mostly gonochoric and a mostly hermaphroditic population (Fell \& Jacob 1979, Simpson 1984). However, the oocytes found in green Haliclona sponges that also produced spermatic cysts were never observed to develop into embryos, unlike hermaphroditic individuals of Halichondria sp. that did produce embryos (Fell \& Jacob 1979). The 'abortive' oocytes observed in this study were significantly smaller than those produced by females, and it seems more probable that environmental factors may be influencing the physiology of those individuals. Sex determination in sponges is thought to be physiological rather than genetic (Simpson 1984). In the present study, oocytes in male green Haliclona were observed during a period of significant cooling of water temperature during February (which starts halfway through January and ends in the first half of March). This cooling is related to the Capes Current, which produces cold water upwelling at Hamelin Bay during the summer months (Gersbach et al. 1999, Pearce \& Pattiaratchi 1999, Hanson et al. 2005). Oocyte development in males was also found in Elvin's (1976) study on the effect of temperature on Haliclona permollis, where oocytes in males and the presence of hermaphroditic individuals occurred after a period of cooling. It is unclear why only a proportion of males is influenced by this temperature change; possibly, individuals in the population are alternating between gonochorism and hermaphroditism (Fell \& Jacob 1979). Manipulative experiments and continued monitoring of the population will confirm or disprove the relationship, but the data suggest that the production of oocytes in green Haliclona males is related to cooling water temperatures.

Table 2. Reproductive strategies and fecundity of various sponge species. Sponges examined in the present study are in bold. $\mathrm{V}$ : viviparous; O: oviparous; G: gonochoric; $\mathrm{H}$ : hermaphroditic; $\mathrm{G} / \mathrm{H}$ : indeterminate sexuality

\begin{tabular}{|c|c|c|c|c|c|c|c|c|}
\hline \multirow{2}{*}{ Species } & \multirow{2}{*}{$\begin{array}{l}\text { Develop- } \\
\text { ment }\end{array}$} & \multirow{2}{*}{ Sexuality } & \multirow[t]{2}{*}{$\mathrm{n}$} & \multicolumn{4}{|c|}{ - Fecundity } & \multirow{2}{*}{ Source } \\
\hline & & & & $\mathrm{o}^{7}\left(\right.$ no. $\left.\mathrm{mm}^{-2}\right)$ & $0^{7}(\%)$ & @ $\left(\right.$ no. $\left.\mathrm{mm}^{-2}\right)$ & ㅇ $(\%)$ & \\
\hline Crambe crambe & $\mathrm{V}$ & & 50 & & & $7.62^{\mathrm{a}}$ & & Uriz et al. (1998) \\
\hline Geodia cydonium & $\mathrm{O}$ & G & 10 & & $0.07-0.21$ & & $0.004-0.2$ & Mercurio et al. (2007) \\
\hline Haliclona amboinensis & $\mathrm{V}$ & $\mathrm{G} / \mathrm{H}$ & 3 & $0.7-1.5^{\mathrm{a}}$ & & $1.3-2.4^{\mathrm{a}}$ & & Fromont (1994a) \\
\hline Haliclona cymiformis & $\mathrm{V}$ & $\mathrm{G} / \mathrm{H}$ & 3 & $0.8-1.6^{\mathrm{a}}$ & & $0.5-0.8^{\mathrm{a}}$ & & Fromont (1994a) \\
\hline Green Haliclona & V & G/H & 68 & $18.2-45.1$ & $0.48-2.34$ & $0.04-0.25$ & $0.01-2.92$ & present study \\
\hline Brown Haliclona & V & G & 62 & $11.4-44.2$ & $0.18-2.39$ & $0.04-0.21$ & $0.01-2.39$ & present study \\
\hline Mycale contarenii & $\mathrm{V}$ & & 360 & & & $0.07-0.2$ & $1.3-1.5$ & Corriero et al. (1998) \\
\hline Niphates nitida & $\mathrm{V}$ & $\mathrm{G} / \mathrm{H}$ & 3 & $0.6-2.4^{a}$ & & $1.6-3.2^{\mathrm{a}}$ & & Fromont (1994a) \\
\hline Rhopaloeides odorabile & $\mathrm{V}$ & G & 181 & $4.6-14$ & $0.72-2.97$ & $0.01-0.13$ & $0.02-1.03$ & Whalan et al. (2007) \\
\hline Scopalina lophyropoda & $\mathrm{V}$ & & & & & $1.25^{\mathrm{a}}$ & & Uriz et al. (1998) \\
\hline Tetilla sp.-deep & & G & 10 & & & 155 & & Meroz-Fine et al. (2005) \\
\hline Tetilla sp.—shallow & & $\mathrm{G}$ & 10 & & & $19.3-88.2$ & & Meroz-Fine et al. (2005) \\
\hline Xestospongia bergquistia & $\mathrm{O}$ & $\mathrm{G}$ & 3 & $5.9^{\mathrm{a}}$ & & $1.8-3.1^{\mathrm{a}}$ & & Fromont (1994a) \\
\hline Xestospongia exigua & $\mathrm{O}$ & $\mathrm{G} / \mathrm{H}$ & 3 & $7.2^{\mathrm{a}}$ & & $10^{\mathrm{a}}$ & & Fromont (1994a) \\
\hline Xestospongia testudinaria & $\mathrm{O}$ & G & 3 & $9.7^{\mathrm{a}}$ & & $1.5-1.9^{\mathrm{a}}$ & & Fromont (1994a) \\
\hline
\end{tabular}




\section{Environmental cues}

Reproduction in both Haliclona species was significantly correlated with decreasing total wave height, although reproduction did coincide with increasing water temperature. The start of reproduction in both species corresponded to a peak in photoperiod. Peak reproductive activity and its association with environmental variables may have important consequences for the reproductive success of both species. Reproduction took place during periods of warm seawater temperatures (generally thought to be needed for spermatogenesis to occur; Simpson 1984) and lower wave action. The primary source of water motion arises from wave action, as tidal influences in the Hamelin Bay region are relatively small (i.e. maximum tidal range of approximately $80 \mathrm{~cm}$ ). Therefore, reproduction during periods of lower wave action may reduce the risks of dilution of gametes and possible unsuccessful fertilisation as a consequence (Oliver \& Babcock 1992). However, this is in contrast to the period of reproductive activity reported for the only other temperate haliclonid species studied in Australia, where development of embryos and larvae occurred during the austral winter (Fromont 1999).

\section{Reproductive output}

Reproduction in females of both green and brown Haliclona occurred over an extended period of 6 and $7 \mathrm{mo}$, respectively. Extended periods of oogenesis have been found for other sponge species (see Riesgo et al. 2007), and may relate to the source of investment (e.g. yolk self-synthesized by oocyte or provided by nurse cells) during the production of the oocytes (Riesgo et al. 2007). The period of oogenesis for both species may be longer than recorded here, as no sampling took place prior to November. However, in green Haliclona no evidence or reproductive activity was found after April, and oocytes were also not observed within brown Haliclona after April. This suggests that reproduction ceases over winter. Moreover, only a few studies have reported oogenesis to extend over most of the year (Riesgo et al. 2007).

Spermatogenesis extended over a period of 3 and 4 mo in green and brown Haliclona, respectively. This is a relatively long period compared to that in some species (in which it may only last a few weeks), but is similar to that reported for Corticium candelabrum and Rhopaloeides odorabile (Riesgo et al. 2007, Whalan et al. 2007). The extended periods of reproductive output observed for both sponge species studied here are likely to be beneficial in the maintenance of both populations by increasing the chances of successful fertilisation (i.e. in males) and release of offspring (i.e. by females) into favourable conditions.

The degree of parental care and its associated energy cost directly influences the reproductive success of an organism (Giese \& Pearse 1974, McEdward 1997). The female reproductive capacities of both species studied here were similar; however, both had reproductive capacities lower than those reported for other haplosclerids and other viviparous sponges (Table 2). Further, the output of females in both haliclonid species was much lower than that in oviparous species (Table 2). Interestingly, a decrease in embryo size was observed for both species over the period of monitoring. This has been observed in other sponge species (e.g. Corticium candelabrum: Riesgo et al. 2007), and was suggested to result from a depletion of maternal energy reserves. Low maternal energy reserves may also account for the low female reproductive output observed here (Ramirez Llodra 2002).

Male reproductive output was similar for both species and higher than the fecundity of other viviparous species, except Rhopaloides odorabile (Table 2). The reproductive output of the species examined here is similar to that reported for some oviparous species (e.g. Xestospongia berquista, $X$. exigua, and X. testudinaria: Fromont 1994a). This high output and the asynchronous development both within and between individuals for each species (suggesting multiple spawning events) may reduce the risk of gamete dilution in the high-energy environment that the species inhabit and increase the chances of successful fertilisation. This is further evidenced by the asynchronous development of female reproductive elements in both species.

The consistency of reproductive output over both reproductive periods (as shown by periodic regression analysis) also suggests that the repeated sampling of tagged individuals had little impact on their reproductive output. Moreover, both species display positive growth $\left(\sim 3\right.$ and $5 \% \mathrm{mo}^{-1}$ for green and brown Haliclona, respectively) during their summer reproductive period (Abdo unpubl. data).

\section{Size and reproductive output}

No relationship between size and reproductive output was found for either Haliclona species. This suggests that small individuals have the same level of reproductive output (per $\mathrm{mm}^{2}$ ) as larger individuals. Early reproductive maturity would benefit the maintenance of each species population by increasing the supply of offspring and, in turn, the chances of successful recruitment. Early sexual maturity has been documented for several species (Fell et al. 1979, Meroz \& Ilan 1995), but determining the age of sexual maturity 
in sponges is difficult to evaluate due to their highly plastic and indeterminate growth patterns (Garrabou \& Zabala 2001). In Mycale fistulifera, it was suggested that early sexual maturity helps maintain and increase the population in the face of limited space and aggressive competition (Meroz \& Ilan 1995). However, a significant correlation was observed for males and females of both species when reproductive output was calculated based on the total volume of the individual, indicating that larger sponges have a greater total reproductive output. Whilst both species reach sexual maturity at an early stage, fecundity clearly increases with the size of sponges. Size-related reproductive output differs among sponge species, reported for some species (Uriz et al. 1995, Whalan et al. 2007), while being absent in others (Ayling 1980, Fromont 1994b). The patterns of reproductive output with body size, found here for both green and brown Haliclona, compare with those found for Rhopaloeides odorabile and Crambe crambe (Uriz et al. 1995, Whalan et al. 2007).

The data on reproductive mode, patterns, fecundity and environmental cues of reproduction in the present study provide valuable information on green and brown haliclonid sponge populations. Both species were found to be viviparous and showed clear gonochorism in brown Haliclona, but a mixed population of hermaphroditic and gonochorism individuals in green Haliclona. Both species' reproduction is closely timed with seasonal changes in environmental conditions, and their extended periods of gametogenesis are likely to increase the chances of fertilisation, offspring survival and recruitment. Further questions still require investigation to gain a complete understanding of the dynamics of each species' population. For example, the factors and processes influencing larval settlement and post-settlement survival are of particularly importance to completing our understanding of the dynamics of a sponge's population. The fundamental reproductive information provided by this study is particularly timely, as green Haliclona is potentially exploitable due to the bioactive compound it produces. Understanding how the sponges reproduce and what may influence their reproduction is critical in determining how each species' population is maintained, which is vital for their effective long-term management and conservation.

Acknowledgements. The authors are indebted to Linda Heap, Alison Abdo, Caine Delacy and Dave Gull for their help during field collections. We thank Tom Stewart for his help with histological processing, and Hai Ngo for his laboratory help and assistance. Thanks are given to Dr G. Kendrick, Dr $\mathrm{S}$. Whalan and Peter Barnes for discussion and comments on the research. The anonymous reviewers of this manuscript are thanked for their comments and suggestions, which have vastly improved this manuscript. Support for this work was provided by the Western Australian Museum and School of Plant Biology (UWA). SeaGIS is also thanked for the provision of ReproMeasure digital imaging software. This research conforms to all laws of Australia.

\section{LITERATURE CITED}

Abdo DA (2007) Endofauna differences between two temperate marine sponges (Demospongiae; Haplosclerida; Chalinidae) from south west Australia. Mar Biol 152:845-854

Abdo DA, Seager JW, Harvey ES, McDonald JI, Kendrick GA, Shortis MR (2006) Efficiently measuring complex sessile epibenthic organisms using a novel photogrammetric technique. J Exp Mar Biol Ecol 339:120-133

Ayling AL (1980) Patterns of sexuality, asexual reproduction and recruitment in some subtidal marine Demospongiae. Biol Bull 158:271-282

Barnes DKA (1995) Sublittoral epifaunal communities at Signy Island, Antarctica. 2. Below the ice-foot zone. Mar Biol 121:565-572

Barnes DKA (1999) High diversity of tropical intertidal zone sponges in temperature, salinity and current extremes. Afr J Ecol 37:424-434

Barthel D (1986) On the ecophysiology of the sponge Halichondria panicea in Kiel Bight. I. Substrate specificity, growth and reproduction. Mar Ecol Prog Ser 32:291-298

Batschelet E (1981) Circular statistics in biology. Academic Press, London

Battershill CN, Bergquist PR (1990) The influence of storms on asexual reproduction, recruitment and survivorship of sponges. In: Rutzler K (ed) New perspectives in sponge biology. Smithsonian Institution Press, Washington, DC, p 397-403

Bergquist PR (1978) Sponges. University of California, Los Angeles

Corriero G, Liaci LS, Marzano CN, Gaino E (1998) Reproductive strategies of Mycale contarenii (Porifera: Demospongiae). Mar Biol 131:319-327

De Weerdt WH (2000) A monograph of the shallow-water Chalinidae (Porifera, Haplosclerida) of the Caribbean. Beaufortia 50:1-67

deBruyn AMH, Meeuwig JJ (2001) Detecting lunar cycles in marine ecology: periodic regression versus categorical ANOVA. Mar Ecol Prog Ser 214:307-310

Doherty PJ (1994) Reproduction and dispersal. In: Hammond LS, Synnot RN (eds) Marine biology. Longman Cheshire, Melbourne, p 168-188

Elvin DW (1976) Seasonal growth and reproduction of an intertidal sponge, Haliclona permollis (Bowerbank). Biol Bull 151:108-125

Ereskovsky AV (2000) Reproduction cycles and strategies of the cold-water sponges Halsarca dujardini (Demospongiae, Halisarcida), Myxilla incustans and Iophon piceus (Demospongiae, Poecilosclerida) from the White Sea. Biol Bull 198:77-87

Erickson KL, Beutler JA, Cardellina JH, Boyd MR (1997) Salicylihalamides A and B, novel cytotoxic macrolides from the marine sponge Haliclona sp. J Org Chem 62:8188-8192

Fell PE (1976) The reproduction of Haliclona loosanoffi and its apparent relationship to water temperature. Biol Bull 150:200-210

Fell PE (1995) Deep diapause and the influence of low temperature on the hatching of the gemmules of Spongilla lacustris (L.) and Eunapius fragilis (Leidy). Invertebr Biol $114: 3-8$ 
Fell PE, Jacob WF (1979) Reproduction and development of Halichondria sp. in the Mystic estuary, Connecticut. Biol Bull 156:62-75

Fell PE, Lewandrowski KB, Lovice M (1979) Postlarval reproduction and reproductive strategy in Haliclona loosanoffi and Halichondri sp. In: Levi C, Boury-Esnault N (eds) Colloques Internationaux du CNRS No. 291-Biologie des spongiaires. Publ CNRS, Paris, p 113-119

Fromont J (1994a) The reproductive biology of tropical species of Haplosclerida and Petrosida on the Great Barrier Reef. In: van Soest RWM, van Kempen TMG, Braekman JC (eds) Sponges in time and space. Balkema, Rotterdam, p 307-312

Fromont J (1994b) Reproductive development and timing of tropical sponges (order Haplosclerida) from the Great Barrier Reef, Australia. Coral Reefs 13:127-133

Fromont J (1999) Reproduction of some demosponges in a temperate Australian shallow water habitat. Mem Queensl Mus 44:185-192

> Garrabou J, Zabala M (2001) Growth dynamics in four Mediterranean demosponges. Estuar Coast Shelf Sci 52:293-303

Gersbach GH, Pattiaratchi CB, Ivey GN, Creswell GR (1999) Upwelling on the south-west coast of Australia - source of the Capes Current? Cont Shelf Res 19:363-400

Giese AC, Pearse JS (1974) Reproduction of marine invertebrates: acoelomate and pseudocoelomate metazoans. Academic Press, New York

Hanson CE, Pattiaratchi CB, Waite AM (2005) Seasonal production regimes off south-western Australia: influence of Capes and Leeuwin Currents on phytoplankton dynamics. Mar Freshw Res 56:1011-1026

Ilan M (1995) Reproductive biology, taxonomy, and aspects of chemical ecology of Latrunculiidae (Porifera). Biol Bull 188:306-312

Ilan M, Loya Y (1990) Sexual reproduction and settlement of the coral reef sponge Chalinula sp. from the Red Sea. Mar Biol 105:25-31

Lepore E, Sciscioli M, Scalera Liaci L, Santarelli G, Gaino E (2000) Sexual reproduction of Cinachyra tarentina (Porifera, Demospongiae). Ital J Zool (Modena) 67:153-158

Lewandrowski KB, Fell PE (1981) Sequential reproduction by different types of specimens of the estuarine sponge, Halichondria sp., with an emphasis on reproduction of postlarval specimens. Invertebr Reprod Dev 3:227-236

Maldonado M, Uriz MJ (1999) Sexual propagation by sponge fragments. Nature 398:476

Mariani S, Uriz MJ, Turon X (2000) Larval bloom of the oviparous sponge Cliona viridis: coupling of larval abundance and adult distribution. Mar Biol 137:783-790

McClintock JB, Baker BJ (2001) Marine chemical ecology. CRC Press, Boca Raton, FL

McEdward LR (1997) Reproductive strategies of marine benthic invertebrates revisited: facultative feeding by planktotrophic larvae. Am Nat 150:48-72

McEdward LR, Miner BG (2003) Fecundity-time models of reproductive strategies in marine benthic invertebrates: fitness differences under fluctuating environmental conditions. Mar Ecol Prog Ser 256:111-121

Mercurio M, Corriero G, Gaino E (2007) A 3-year investigation of sexual reproduction in Geodia cydonium (Jameson, 1811) (Porifera, Demospongiae) from a semi-enclosed Mediterranean bay. Mar Biol 151:1491-1500

Meroz E, Ilan M (1995) Life history characteristics of a coral reef sponge. Mar Biol 124:443-451

Meroz-Fine E, Shefer S, Ilan M (2005) Changes in morphology and physiology of an East Mediterranean sponge in different habitats. Mar Biol 147:243-250

Munro MHG, Blunt JW, Dumdei EJ, Hickford SJH and others (1999) The discovery and development of marine compounds with pharmaceutical potential. J Biotechnol 70: $15-25$

Oliver J, Babcock RC (1992) Aspects of fertilisation ecology of broadcast spawning corals: sperm dilution effects and in situ measurements of fertilisation. Biol Bull 183:409-418

Paul VJ, Puglisi MP, Ritson-Williams R (2006) Marine chemical ecology. Nat Prod Rep 23:153-180

- Pearce A, Pattiaratchi C (1999) The Capes Current: a summer counter current flowing past Cape Leeuwin and Cape Naturaliste, Western Australia. Cont Shelf Res 19: 401-420

Ramirez Llodra E (2002) Fecundity and life-history strategies in marine invertebrates. Adv Mar Biol 43:87-170

Riesgo A, Maldonado M, Durfort M (2007) Dynamics of gametogenesis, embryogenesis, and larval release in a Mediterranean homsclerophorid demosponge. Mar Freshw Res 58:398-417

Simpson TL (1980) Reproductive processes in sponges: a critical evaluation of current data and views. Invertebr Reprod Dev 2:251-269

Simpson TL (1984) The cell biology of sponges. SpringerVerlag, New York

Tsurumi M, Reiswig HM (1997) Sexual versus asexual reproduction in an oviparous rope-form sponge, Aplysina cauliformis (Porifera; Verongida). Invertebr Reprod Dev 32:1-9

Uriz MJ, Maldonado M, Turon X, Marti R (1998) How does reproductive output, larval behaviour, and early recruitment contribute to adult spatial patterns in Mediterranean encrusting sponges? Mar Ecol Prog Ser 167:137-148

Uriz MJ, Turon X, Becerro MA, Galera J, Lozano J (1995) Patterns of resource allocation to somatic, defensive, and reproductive functions in the Mediterranean encrusting sponge Crambe crambe (Demospongiae, Poecilosclerida). Mar Ecol Prog Ser 124:159-170

Usher KM, Sutton DC, Toze S, Kuo J, Fromont J (2004) Sexual reproduction in Chondrilla australiensis (Porifera: Demospongiae). Mar Freshw Res 55:123-134

Wapstra M, van Soest RWM (1987) Sexual reproduction, larval morphology and behaviour in demosponges from the southwest of the Netherlands. In: Vacelet J, Boury-Esnault $\mathrm{N}$ (eds) Taxonomy of Porifera from the N. E. Atlantic and Mediterranean Sea. Springer-Verlag, New York, p 281-307

Whalan S, Johnson MS, Harvey ES, Battershill C (2005) Mode of reproduction, recruitment, and genetic subdivision in the brooding sponge Haliclona sp. Mar Biol 146:425-433

Whalan S, Battershill C, de Nys R (2007) Sexual reproduction of the brooding sponge Rhopaloeides odorabile. Coral Reefs 25:297-301

Witte U (1996) Seasonal reproduction in deep sea sponges Triggered by vertical particle flux? Mar Biol 124:571-581

> Witte U, Barthel D, Tendal O (1994) The reproductive cycle of the sponge Halichondria panicea Pallas (1766) and its relationship to temperature and salinity. J Exp Mar Biol Ecol 183:41-52

Wulff JL (1991) Asexual fragmentation, genotype success, and population dynamics of erect branching sponges. J Exp Mar Biol Ecol 149:227-247

Zar JH (1999) Biostatistical analysis. Prentice Hall, Engelwood Cliffs, NJ

Zilberberg C, Maldonado M, Sole-Cava AM (2006) Assessment of the relative contribution of asexual propagation in a population of the coral excavating sponge Cliona delitrix from the Bahamas. Coral Reefs 25:297-301 